http://jmscr.igmpublication.org/home/ ISSN (e)-2347-176x ISSN (p) 2455-0450 crossref DOI: https://dx.doi.org/10.18535/jmscr/v8i1.17

\title{
A cross sectional study on Knowledge, Awareness and Practices regarding Breast Cancer among the women of reproductive age group (25-45 years) attending a peripheral health centre in North India
}

\author{
Authors \\ Dr Ruqia Quansar ${ }^{1}$, Dr Mohsina Mukhtar ${ }^{2 *}$, Dr Sajad Tak ${ }^{3}$, Dr S M Salim Khan ${ }^{4}$ \\ ${ }^{1,2}$ Senior Resident, Department of Community Medicine, Government Medical College Srinagar, Jammu and Kashmir \\ ${ }^{3}$ Senior Resident, Department of General Medicine, Government Medical College Srinagar, Jammu and Kashmir \\ ${ }^{4}$ Professor and Head, Department of Community Medicine, Government Medical College, Srinagar, \\ Jammu and Kashmir \\ *Corresponding Author \\ Dr Mohsina Mukhtar \\ Department of Community Medicine, Government Medical College Srinagar, Jammu and Kashmir, India
}

\begin{abstract}
Background: Breast cancer $(B C)$ continues to be a major cause of morbidity and mortality throughout the world. Early detection and treatment of BC increases the chances of survival. According to Breast Health Global Initiative guidelines for low and middle income countries, diagnosing BC early by promoting breast self-awareness, clinical breast examination (CBE) and resource adapted mammographic screening will reduce $B C$ mortality.

Methodology: A hospital based cross sectional study was conducted in semi-urban area of District Srinagar. Women of reproductive age group (25- 45 years) were interviewed after taking their consent. A total of 189 women were interviewed using a pre-structured questionnaire.

Results: In our study, majority of women were in the age group of 31-35 years (32.8\%), illiterate (37.5\%), belonging to joint families (70.1\%) and married (75.1\%). 53.4\% women had heard about BC, $58.4 \%$ women had heard about BSE and $8.5 \%$ women had ever practiced BSE.

Conclusion: Overall the knowledge, awareness and practices were poor among the women interviewed. There is a need for imparting awareness regarding the preventability and early detection of breast cancer through breast self-examination and thus indirectly decreasing the morbidity and mortality.

Keywords: Breast cancer, Breast self-examination, Knowledge, Awareness, Practice.
\end{abstract}

\section{Introduction}

The breast development occurs in distinct stages throughout a woman's life starting from birth to puberty, during menstruation period, child bearing age and till the woman reaches menopause. As soon as ovulation and menstruation begins, the breast starts maturing and continues to grow. Women may also experience changes in breast texture as age advances ${ }^{(1)}$. Breast cancer is an uncontrolled growth of cells which occurs as a result of mutations or abnormal changes in the genes responsible for the growth of cells and keeping them healthy. Usually breast cancer either begins in the cells of the lobules which are the milk producing glands or the ducts and the passages that drain milk from the lobules to the nipple $^{(2)}$. 
Breast cancer is a major life-threatening public health concern. Long term increase in the incidence of the disease is being observed in both industrialized and developing world. Breast cancer is the second most occurring cancer (cervical cancer is first) among women ${ }^{(3)}$. Almost $70 \%$ of women aged over 50 years suffer from breast cancer and only $5 \%$ are younger than 40 years ${ }^{(4)}$. In India, cancer prevalence is estimated around 2.5 million, with over 0.8 million new cases and 0.5 million deaths occurring each year. Breast cancer accounts for $19 \%-34 \%$ of all cancer cases among women in India ${ }^{(5)}$.

Risk factors for breast cancer are multiple and synergistic. Family history and genetic factors are important risk factors. Reproductive factors such as early menarche, late menopause, and a late age at first childbirth are also associated with increased incidence of breast cancer. Women using oral contraceptive pills or hormone replacement therapy are at a greater risk than others. Lack of breast feeding is also associated with it. Lifestyle factors such as diet, physical activity, overweightness, and obesity also affect the occurrence of breast cancer ${ }^{(6)}$.

Breast cancer is still considered a social stigma in India. There are numerous myths and ignorance in the Indian society which results in unrealistic fear of the disease ${ }^{(7)}$. Evidence shows that women who seek treatment at an early stage have better chances of survival. For detection at an early stage, women should be aware of the disease, its symptoms and of simple prevention strategies such as breast self-examination. Therefore, it is crucial to understand women's attitude towards breast cancer in order to develop effective strategies for early detection and prevention of breast cancer ${ }^{(8)}$.

\section{Aim and Objectives}

The study was done to assess the knowledge, attitude and practice regarding the breast selfexamination and breast cancer in women of reproductive age.

\section{Methodology}

A cross-sectional hospital based study was conducted from July 2018 to September 2018 to assess Knowledge Awareness and Practices regarding Breast Cancer and Breast Self Examination among women of reproductive age group (25-45 years) attending two peripheral health centres of Block Hazratbal, District Srinagar. Block Hazratbal is under the administrative control of Department of Community Medicine, Government Medical College Srinagar and has been divided into four health zones for administrative convenience. The women in the reproductive age group (25-45 years) attending the gynaecology and obstetrics OPD at the health centre were included in the study. The study was conducted during a time period of 3 months during which a total of 189 women in the reproductive age group (25-45 years), who consented to participate, were included in the study. Informed verbal consent was obtained from eligible women. Participants were explained the objectives of the study and were interviewed using a structured questionnaire. Information was obtained regarding demographic and socio-economic characteristics and reproductive history was also recorded. The knowledge regarding the causes and symptoms of the breast cancer was assessed. The knowledge regarding breast self-examination was also assessed. The collected data was entered in Microsoft Excel Data and was described in terms of percentages.

\section{Results}

The majority of the women who participated belonged to the age group of $31-35$ years $(32.8 \%)$, were illiterate $(37.5 \%)$, belonged to a joint family $(70.4 \%)$, were homemakers $(70.9 \%)$, and were married $(75.1 \%)$. [Table 1] 
Table 1: Socio - demographic characteristics of participants

\begin{tabular}{|l|c|c|}
\hline Characteristic & $\begin{array}{c}\text { Number } \\
(\mathrm{n}=189)\end{array}$ & $\begin{array}{c}\text { Percentage } \\
(\%)\end{array}$ \\
\hline Age (years) & 35 & 18.5 \\
\hline $25-30$ & 62 & 32.8 \\
\hline $31-35$ & 50 & 26.5 \\
\hline $36-40$ & 42 & 22.2 \\
\hline $41-45$ & 71 & 37.5 \\
\hline Education level & 43 & 22.7 \\
\hline Illiterate \\
\hline Primary \\
\hline Middle \\
\hline High school & 29 & 15.5 \\
\hline Higher secondary & 12 & 10.5 \\
\hline Graduate & 6.5 \\
\hline $\begin{array}{l}\text { Post graduate and } \\
\text { above }\end{array}$ & 5 & 4.8 \\
\hline Family type & 2.5 \\
\hline Nuclear \\
\hline Joint \\
\hline Marriage status & 133 & 29.6 \\
\hline Unmarried & 47 & 70.4 \\
\hline Married & 24.9 \\
\hline Working & 142 & 75.1 \\
\hline Yes \\
\hline No & 55 & 29.1 \\
\hline
\end{tabular}

101 women $(53.4 \%)$ had actually heard about the Breast Cancer out of total participants. The women who had heard about breast cancer were further questioned regarding their source of information, awareness about symptoms and awareness about the risk factors. [Table 2]

Table 2: Knowledge and awareness regarding breast cancer among the participants

\begin{tabular}{|l|c|c|}
\hline \multicolumn{2}{|l|}{ Number (n=101) } & Percentage (\%) \\
\hline Heard about Breast cancer \\
\hline Yes & 101 & 53.4 \\
\hline No & 88 & 46.6 \\
\hline Source of information & \multicolumn{2}{|l|}{} \\
\hline TV / Radio & 22 & 21.7 \\
\hline Family & 39 & 38.7 \\
\hline Friends & 34 & 33.7 \\
\hline Others & 6 & 5.9 \\
\hline Knowledge about symptoms & 32.7 \\
\hline Lump in the breast & 33 & 23.8 \\
\hline Pain in the breast & 24 & 10.9 \\
\hline $\begin{array}{l}\text { Discharge from } \\
\text { nipples }\end{array}$ & 11 & 20.8 \\
\hline Axillary lump & 21 & 11.8 \\
\hline Don't know & 12 & 13.9 \\
\hline Knowledge about risk factors & 32.6 \\
\hline OCP intake & 14 & 23.8 \\
\hline Family history & 33 & 10.9 \\
\hline Curse & 24 & 6.9 \\
\hline Diet history & 11 & 11.9 \\
\hline Late pregnancy & 7 & \\
\hline Don't know & 12 & \\
\hline
\end{tabular}

The knowledge regarding the prevention and treatment of breast cancer was also assessed among the participants who had heard about Breast Cancer. [Table 3]

Table 3: Knowledge and awareness regarding prevention and treatment of breast cancer

\begin{tabular}{|l|c|c|}
\hline & Number $(\mathrm{n}=101)$ & Percentage (\%) \\
\hline \multicolumn{2}{|l|}{ Knowledge about prevention } \\
\hline $\begin{array}{l}\text { Check up by } \\
\text { Doctor }\end{array}$ & 31 & 30.7 \\
\hline $\begin{array}{l}\text { Breast - self } \\
\text { examination }\end{array}$ & 29 & 28.7 \\
\hline $\begin{array}{l}\text { Cannot be } \\
\text { prevented }\end{array}$ & 24 & 23.8 \\
\hline Don't know & 17 & 16.8 \\
\hline Knowledge about treatment \\
\hline Curable & 34 & 33.7 \\
\hline In curable & 45 & 44.5 \\
\hline Don't know & 22 & 21.8 \\
\hline
\end{tabular}

The knowledge and practice regarding the Breast Self Examination (BSE) was assessed among the participants. Out of 101 subjects who were aware about Breast Cancer, 59 had heard about Breast Self Examination. [Table 4]

Table 4: Knowledge and practice regarding the breast self-examination (BSE)

\begin{tabular}{|c|c|c|}
\hline & Number & Percentage $(\%)$ \\
\hline \multicolumn{3}{|l|}{ Heard about BSE $(n=101)$} \\
\hline Yes & 59 & 58.4 \\
\hline No & 42 & 41.6 \\
\hline \multicolumn{3}{|c|}{ Practice of BSE ever $(n=59)$} \\
\hline Yes & 5 & 8.5 \\
\hline No & 54 & 91.5 \\
\hline \multicolumn{3}{|c|}{ Cause of non-practice of BSE $(n=54)$} \\
\hline Fear & 12 & 22.2 \\
\hline Embarrassment & 21 & 38.9 \\
\hline Lack of knowledge & 13 & 24.1 \\
\hline Forgetfulness or too busy & 8 & 14.8 \\
\hline
\end{tabular}

\section{Discussion}

Breast cancer, if diagnosed in early stages, is one of the preventable cancers. Treatment and survival is directly related to the stage at diagnosis. The earlier the breast cancer is diagnosed the better the survival rates. There is thus considerable potential for reducing mortality from breast cancer in populations by detecting breast cancer early ${ }^{(7)}$. In India, women seek medical care at the advance stages when the mortality rate is high. Several reasons for late reporting have been found, of 
which lack of awareness, poor health seeking behaviour and shyness on part of patients are major ones ${ }^{(9)}$. There are no known proven means to prevent breast cancer, which increases our reliance on the methods for early detection in order to improve patient outcomes ${ }^{(4)}$.

Undoubtedly, screening can be efficient in reducing the mortality in two malignancies viz breast and cervical carcinoma. In developing countries such as India, appropriate knowledge and attitude of the community may be the most important necessity for early detection and screening program of breast cancer ${ }^{(10)}$. A review of the literature reveals low breast cancer literacy with regard to risk factors among Indian women, irrespective of their socio-economic and educational backgrounds, with little correlation between awareness levels and strength of evidence of the risk factors ${ }^{(5)}$.

In our study, majority of the women belonged to the age group of $31-35$ years (32.8\%) followed by the age group of $36-40$ years $(26.5 \%)$, followed by 41-45 years $(22.2 \%)$ and the least percentage being that of 25-30 years (18.5\%). Majority of the women were illiterate $(37.5 \%)$ followed by women being educated up-to primary level $(22.7 \%)$ followed by middle level (15.5\%), followed by high school level (10.5\%) and higher secondary level (6.8\%)and least being educated up-to graduate and postgraduate level. The majority of the women belonged to joint families (70.4\%), were married $(75.1 \%)$, and were homemakers $(70.9 \%)$.

In our study, out of total 189, 101 (53.4\%) women had heard about breast cancer. The source of information in the majority cases was from family (mother/sister) (38.7\%), followed by friends (33.7\%) and around $21.7 \%$ had TV or Radio as their source of information.

Regarding knowledge of symptoms, majority responded with lump in the breast as a symptom $(32.7 \%)$, followed by pain in the breast $(23.8 \%)$, followed by axillary lump (20.8\%), and followed by discharge $(10.9 \%)$ while $11.8 \%$ didn't have any knowledge regarding the symptoms.
Regarding the knowledge of risk factors, majority had the knowledge of family history as a risk factor $(32.6 \%)$,followed by curse $(23.8 \%)$, followed by OPC intake (13.9\%), diet (10.9\%), and late pregnancy $(6.9 \%)$ while $11.9 \%$ didn't have any knowledge regarding the risk factors.

The knowledge regarding preventability was also assessed and majority of the women had the knowledge that check up by doctor $(30.7 \%)$ can help prevent breast cancer, followed by BSE $(28.7 \%)$ as a preventive remedy. $23.8 \%$ women had a view that breast cancer could not be prevented at all. $16.8 \%$ women didn't know if breast cancer was preventable or not.

$33.7 \%$ women had a knowledge that breast cancer was curable and $44.5 \%$ believed that breast cancer was not curable while $21.8 \%$ women didn't know if breast cancer was curable or not.

Regarding breast self-examination, (BSE), 58.4\% (59) women had heard about it, and only $8.5 \%$ (54) had ever practised BSE at home. The majority of the women reported embarrassment $(38.8 \%)$ as a cause of non- practice of BSE, followed by fear (22.2\%), followed by lack of knowledge (24.1\%).

\section{Conclusion}

This study has shown that though awareness regarding breast cancer was considerable but there waspoor knowledge about risk factors and screening test. Breast self -examination which is most sensitive and cost effective method for early detection of cancer was known by few women and very few of them practiced it regularly. Therefore it is important to educate the women about breast cancer and its risk factors, eliminate the misconception and promote screening for early detection $^{(9)}$. Many women showed very less favourable attitude towards breast self examination which can be corrected or made more favourable by educating them about the correct technique and skills of performing breast self examination right from the age of adolescence in the form of formal education as well as informal education $^{(2)}$. 
Indian women need to be aware of both modifiable and non-modifiable risk factors for breast cancer to adopt appropriate practices for prevention. Breast cancer is a topic that is not freely discussed in India because of the cultural taboo. Hence, there is an urgent call for more effective nation and state- wide cancer literacy programs, as well as engagements with community- level organizations and health systems. The government should utilize good examples of famous personalities who have revived from the disease. Health education at the college level, regarding various aspects ranging from risk factors to various methods of screening, should be done more aggressively. BSE should be encouraged actively especially in women with a family history ${ }^{(5)}$.

\section{References}

1. Shadap A, Pais M, Prabhu A. A descriptive study to assess the knowledge on breast cancer and utilization of mammogram among women in selected villages of Udupi District, Karnatka. Nitte Univ J Heal Sci. 2014;4(4):84-7.

2. Sharma P, Dillu R. Study to Assess the Knowledge and Attitude about Breast Cancer and Breast Self Examination among Women of 20-50 Years of Age in a Selected Hospital of Haryana. Int J Sci Res. 2017;6(5):270-7.

3. Lemlem SB, Sinishaw W, Hailu M, Abebe M, Aregay A. Assessment of Knowledge of Breast Cancer and Screening Methods among Nurses in University Hospitals in Addis Ababa , Ethiopia , 2011. Hindawi Publ Corp. 2015;2013:1-8.

4. Amal SK. Awareness and attitudes regarding breast cancer and breast self examination among female Jordanian students. J Basic Clin Pharm. 2014;5(3):74-8.
5. Madhukumar S, Thambiran UR, Basavaraju B, Bedadala MR. A study on awareness about breast carcinoma and practice of breast self - examination among basic sciences ' college students , Bengaluru. J Fam Med Prim Care. 2017;6:487-90.

6. Santhanakrishnan N, Prabakaran S, Singh Z. Knowledge, attitude, and practice regarding breast cancer and its screening methods among nursing staff working in a tertiary-care hospital located in South India. Int $\mathbf{J}$ Med Sci Public Heal. 2016;5(08).

7. Kumar M, Kashyap V. Awareness about breast cancer among women attending obstetrics and gynaecology department in a tertiary care hospital of Jharkhand, India. Int J Community Med Public Heal. 2016;3(4):938-43.

8. Gangane N, Ng N, Sebastián MS. Women 's Knowledge, Attitudes, and Practices about Breast Cancer in a Rural District of Central India. Asian pacific J cancer Prev. 2015;16(16):6863-70.

9. Ahmad SR, Ameer SR, Chandrasekhar A. A study to assess the knowledge and belief of female towards breast cancer and its screening practices in Hyderabad, India. Natl J Res Community Med. 2017;6(2):116-9.

10. Nahid N, Masoud S, Kalantar MMH, Mohammad AE. A survey of breast cancer knowledge and attitude in Iranian women. J Cancer Res Ther. 2012;8(1):46-9. 